William Bernet, ${ }^{1}$ M.D.; Cindy L. Vnencak-Jones, ${ }^{2}$ Ph.D.; Nita Farahany, ${ }^{3}$ J.D., Ph.D.; and Stephen A. Montgomery, ${ }^{4}$ M.D.

\title{
Bad Nature, Bad Nurture, and Testimony Regarding MAOA and SLC6A4 Genotyping at Murder Trials*
}

\begin{abstract}
Recent research—in which subjects were studied longitudinally from childhood until adulthood—has started to clarify how a child's environment and genetic makeup interact to create a violent adolescent or adult. For example, male subjects who were born with a particular allele of the monoamine oxidase A gene and also were maltreated as children had a much greater likelihood of manifesting violent antisocial behavior as adolescents and adults. Also, individuals who were born with particular alleles of the serotonin transporter gene and also experienced multiple stressful life events were more likely to manifest serious depression and suicidality. This research raises the question of whether testimony regarding a defendant's genotype, exposure to child maltreatment, and experience of unusual stress is appropriate to present during the guilt or penalty phases of criminal trials, especially when capital punishment is a consideration. The authors present their experience in genotyping criminal defendants and presenting genetic information at criminal trials.
\end{abstract}

KEYWORDS: forensic science, psychiatry, genotyping, monoamine oxidase gene, serotonin transporter gene, serotonin, mitigation, capital punishment, expert testimony

Mental health professionals have thought for many years that violent behavior is partly caused by a person's life experiences and partly by genetic influences. Recent research-in which subjects were studied longitudinally from childhood until adulthood-has started to clarify how a child's environment, his subsequent exposure to stressful life events and his genetic makeup may interact to create an increased risk for violence and other mental disorders in adolescence and adulthood. This interaction between genetic loci and life experiences is called gene $\times$ environment $(\mathrm{G} \times \mathrm{E})$ interaction.

We agree with Paul S. Appelbaum, who said, "Recent research findings...suggest that behavioral genetics may be the next frontier for the world of criminal justice, and mental health professionals are likely to play a critical role in helping the courts make sense of the new data" (1). Other experts, Popma and Raine, said, "Exciting progress is being made in the knowledge concerning genetic contributions to antisocial behavior and the interplay of genetic factors with the environment. ... One probable important pathway is that genetic factors influence biologic factors, such as arousal and hormonal levels, as well as specific aspects of brain functioning, which in turn influence behavior" (2).

For example, Caspi et al. (2002) (3) studied the monoamine oxidase $\mathrm{A}(M A O A)$ gene. When there is a low activity of this gene,

\footnotetext{
${ }^{1}$ Department of Psychiatry and Vanderbilt Forensic Services, Vanderbilt University School of Medicine, Nashville, TN 37212.

${ }^{2}$ Molecular Genetics Laboratory, Departments of Pathology and Pediatrics, Vanderbilt University School of Medicine, Nashville, TN 37212.

${ }^{3}$ Vanderbilt University Law School, Nashville, TN 37212.

${ }^{4}$ Department of Psychiatry, Vanderbilt University School of Medicine, Nashville, TN 37212.

*An earlier version of this paper was presented by Dr. Bernet and Dr. Farahany at the 58th Annual Meeting of the American Academy of Forensic Sciences, Seattle, WA, February 20-25, 2006.

Received 14 July 2006; and in revised form 24 Feb. 2007; accepted 29 April 2007; published 21 Dec. 2007.
}

neurotransmitters in the brain (serotonin, dopamine, and norepinephrine) are not properly metabolized. They found that when male subjects had a low activity of MAOA and also were maltreated as children, there was a much greater likelihood the person would manifest violent antisocial behavior in the future. Also, Caspi et al. (2003) (4) studied the 5-HTT (5-hydroxytryptamine or serotonin transporter) or SLC6A4 gene. They found that individuals with one or two copies of the short allele "exhibited more depressive symptoms, diagnosable depression, and suicidality in relation to stressful life events" than individuals with two long alleles.

Information regarding a defendant's genotype, exposure to child maltreatment, and experience of unusual stress may be appropriate to present during the guilt and penalty phases of criminal trials, especially when capital punishment is a consideration. This paper summarizes both historical and recent research regarding possible biopsychosocial causes of violence, summarizes the history of court testimony regarding these issues, and relates our experience in conducting MAOA and SLC6A4 genotyping and testifying regarding these topics in criminal trials.

\section{The Search for the Causes of Violent Behavior}

Early attempts to explain criminal behavior on the basis of inherited genetic predisposition focused on phenotype rather than genotype. In the late nineteenth century, Lombroso attempted to predict criminality based on "primitive" physical characteristics such as strong jaws, heavy brows, bloodshot eyes, thick lips, and projecting ears $(5,6)$. While these characteristics may have correlated to some degree with low intelligence and some rare genetic syndromes, they were far from being valid indicators of criminality.

Sheldon also put forth a theory of criminality based on physical characteristics. He hypothesized that a mesomorphic or muscular body type was predictive of criminal behavior (7). Although some research has supported a mild association with degree of 
mesomorphy and criminality, it is not a consistent finding and certainly does not explain the vast majority of criminal behavior.

Many researchers have studied families of criminals and have consistently found higher rates of criminal behavior among offspring of criminals. This suggests a genetic component to criminality but does not sufficiently account for environmental influences. Twin and adoption studies have attempted to separate these variables. For example, Kendler and Prescott (8) and other researchers at the Virginia Adult Twin Study of Psychiatric and Substance Use Disorders have studied several thousand sets of twins for more than 20 years. They have shown that conduct disorder in adolescents and antisocial behavior in adults is related to both genetic and environmental factors, and they demonstrated gene $\times$ environment interactions.

The focus on genotype rather than phenotype was addressed at the chromosomal level. Men with an XYY karyotype were once thought to be more aggressive and violent, but this theory was largely disproved by larger, population-based studies. However, the presence of the extra $\mathrm{Y}$ chromosome may confer some greater risk for antisocial behavior because of an association with learning problems and low intelligence $(9,10)$.

With an understanding of molecular genetics and completion of the human genome project, scientists are able to isolate specific genes and inch closer to uncovering the secrets of the "black box" of genetics that were only inferred by the classical approaches described above. Much research has focused on genes involving major neurotransmitters such as serotonin and dopamine and proteins that affect these neurotransmitters. No research has yet to isolate a specific "crime gene" and probably none ever will. Some of the reasons this is unlikely are incomplete penetrance, genetic heterogeneity, and the complex interaction among environmental factors, development, and gene expression.

\section{Testimony Regarding $M A O A$ Genotyping}

Although criminal defendants have introduced evidence of genetic predispositions to violence, alcoholism, antisocial personality disorder, and other associated traits in criminal trials, specific genotyping evidence has been introduced on an extremely limited basis $(11,12)$. Owing in part to procedural hurdles and in part to the inadequacy of the science in establishing a link between a defendant's biological make-up and the specific alleged criminal act, genetic predisposition evidence has had only limited effect in criminal cases. New advances in behavioral sciences may enable a greater impact of such evidence in future criminal cases. The few reported cases in which evidence pertaining to the MAOA gene or serotonin has been introduced in criminal trials are summarized here. Of course, testimony regarding the MAOA gene and serotonin may have been introduced in other cases, including some cases without written opinions or cases where the opinion makes no mention of the genetic testimony introduced.

\section{Mobley v. State}

The 1994 criminal case of Stephen A. Mobley is the sole reported case referencing $M A O A$ genotyping (13). Mobley was convicted of murder, armed robbery, aggravated assault, and possession of a firearm during the commission of a crime and was sentenced to death. At trial, Mobley filed a motion seeking funds to hire expert witnesses to assess his potential deficiency in MAOA enzymatic activity, based on the then-recent studies suggesting "a possible genetic basis for violent and impulsive behavior in certain individuals," and his family history of violence (14). This motion was based on a recently published study by Brunner et al. (15), in which a family in The Netherlands was identified in which very violent individuals had a specific mutation of the MAOA gene. The trial court denied Mobley's motion, finding that the link between the MAOA gene and violence lacked scientific verifiability sufficient for it to be introduced during the sentencing phases of his capital trial. On March 1, 2005, Mobley was executed by lethal injection by the state of Georgia.

\section{Testimony Regarding Serotonin}

No published court opinion documents the use of serotonin transporter gene (SLC6A4) genotyping as evidence during trial. Expert testimony has been cited, however, regarding a defendant's serotonin level in the central nervous system, its effect on impulse control, the consequent ability of the defendant to form the requisite intent for the alleged crime, and to mitigate a defendant's culpability for sentencing. What follows is a summary of the few cases in which expert testimony regarding a defendant's serotonin levels was referenced in court opinions.

\section{State v. Jon Hall}

Jon Hall was convicted of the 1994 first-degree murder of his estranged wife (16). During a postconviction hearing on appeal, Hall's lawyers presented an expert witness who testified Hall had low serotonin levels in his brain, consistent with intermittent explosive disorder. Another expert explained that low levels of serotonin serve as a biological marker for intermittent explosive disorder and that the scientific literature confirmed a "correlation between low levels of serotonin in the brain and violent acts" (p. 16) (16). The expert concluded that Hall was "unable...to achieve the mental state of the absence of passion and excitement," necessary for a finding of criminal liability (p. 18) (16). The state responded with expert testimony rebuking these claims. The state's expert testified that measuring serotonin in the cerebrospinal fluid (CSF) lacked utility as a diagnostic tool because it failed to give an accurate indication of the serotonin levels in the synapses where it operates and that there was no consensus on what constitutes normal levels of serotonin. The procedural posture of the case rendered the dispute between the experts irrelevant; the theory of intermittent explosive disorder was unavailable at the time of Hall's trial, and presented only later on appeal. The unavailability of the theory at the time of trial undermined Hall's claim of ineffective assistance of counsel at trial for failure to present the theory as a defense. Hall's conviction and death sentence were affirmed.

\section{Hines v. State}

Similarly, Anthony Darrell Hines, originally tried and convicted of first-degree felony murder and sentenced to death in 1986, failed on his claim of ineffective assistance of counsel for failure to introduce evidence of his low serotonin levels during his 1989 re-sentencing hearing (17).

\section{State v. Payne}

In two other murder cases in Tennessee, defense counsel proceeded on analogous defense theories. In State v. Payne, Derek T. Payne was charged with a two-count indictment of first-degree premeditated murder, first-degree felony murder, and one count of 
criminal attempt to commit especially aggravated robbery (18). The jury found him guilty of the lesser-included offense of second-degree murder and attempted especially aggravated robbery, and he was sentenced to 37 years in prison. A molecular neurobiologist provided expert testimony during trial that Payne had statistically low serotonin levels, and explained the interrelationship between serotonin and human behavior. The neurobiologist also testified that "the research in the field has consistently shown a link between low serotonin levels and 'explosive intermittent violence"" (p. 5) (18). Although he acknowledged that low serotonin itself does not cause violence, the neurobiologist concluded that Payne's "capacity to control [an] impulse once it had occurred [was] virtually nonexistent" (p. 5) (18). In accord with the scientific literature, however, the neurobiologist opined that serotonin would be relevant only to a crime of impulse, rather than a planned or premeditated one.

The expert testimony was introduced for several purposes: (1) to claim Payne could not form the requisite mental state required for first or second-degree murder because of his low serotonin levels; (2) to support the claim that Payne committed voluntary manslaughter because he acted based on provocation by the victim and lack of impulse control; and (3) as mitigating evidence during sentencing. Prior to deliberations, the court instructed the jury that Payne's mental condition could have affected his capacity to form the requisite mental state for the particular offense. The jury found Payne guilty of the lesserincluded offense of second-degree murder, thereby rejecting his claims. The appellate court affirmed, explaining that although Tennessee recognizes the defense of diminished capacity, the jury reasonably could have rejected Payne's defense to seconddegree murder, relying instead upon the circumstantial evidence suggesting that Payne premeditated the murder rather than acting impulsively. Notably, the jury did not convict Payne of firstdegree murder. The jury instructions and limited evidence Payne introduced to negate his mental state-his low serotonin level and laboring under the influence of alcohol and cocaine during the crime - could suggest that the jury's decision to find Payne guilty of second-rather than first-degree murder was impacted by the expert testimony. The appellate court concluded that Payne's subjective serotonin level was irrelevant, however, to the defense of provocation (and therefore voluntary manslaughter), which is judged by the external circumstances of the crime, rather than the internal mental state of the defendant. Finally, the appellate court agreed that Payne's low serotonin levels could be afforded little weight as mitigating evidence because the circumstances of the crime suggested that Payne did not act impulsively, but in a calculated manner.

\section{State v. Godsey}

A similar defense of diminished capacity was raised in State $v$. Godsey, in which Garland Godsey was indicted for premeditated first-degree murder, but convicted of the lesser-included offense of second-degree murder and sentenced to 25 years incarceration (19). At trial, the defense introduced expert testimony diagnosing the defendant with intermittent explosive disorder, suggesting he has only an extremely limited capacity to control his aggressive impulses, and thereby could not form the requisite mental state required for first- or second-degree murder. In addition, the defense introduced testimony that Godsey was inebriated during the commission of the homicide and therefore acted in an impulsive rather than premeditated fashion. Godsey, too, was convicted of secondrather than first-degree murder.

\section{People v. Uncapher}

Low brain serotonin level has also been introduced as a defense in other jurisdictions. In People v. Kenneth John Uncapher, a Michigan trial court excluded expert testimony diagnosing Uncapher with low levels of serotonin, and testimony linking low levels of serotonin with poor impulse control (20). Uncapher's lawyers sought to introduce this testimony to support the claim that Uncapher "had 'biological' problems that diminished his ability to reason and control his impulses" (p. 1) (20). The Michigan trial court found such testimony impermissible because Michigan law prohibits the use of a defendant's psychological or biological condition to rebut his capacity to form the requisite mental state for the alleged crime. Instead, such evidence is permissible in Michigan only in support of an insanity defense.

\section{State v. Sanders}

An Ohio trial court similarly excluded expert testimony regarding a defendant's bipolar affective disorder, aggravated by low serotonin levels in the defendant's brain, and his consequent impaired capacity to control his impulsive behavior (21). The defendant, Dion Wayne Sanders, claimed that the testimony would prove that he was "incapable of acting with the degree of culpability which the charges of Aggravated Murder involved" (p. 1) (21). The State objected to the testimony, arguing that diminished capacity is not a defense to criminal liability, and is admissible only in support of an insanity defense. The trial court excluded the testimony, and the appellate court affirmed, finding that " $[\mathrm{w}]$ hether an accused acted out of a sense or attitude of rage is not relevant to prove that he acted or did not act 'purposefully' and 'with prior calculation and design.' ... It could not demonstrate that when he shotgunned his grandparents Sanders lacked the specific intent to kill them. It only demonstrates that he was enraged when he did" (p. 2) (21).

Other jurisdictions that prohibit the defense or evidentiary rule of diminished capacity may likewise prohibit the use of $M A O A$ and SLC6A4 genotyping evidence to negate the defendant's capacity to form the requisite intent for the crime. In those jurisdictions, such evidence may still be relevant to the insanity defense or during sentencing. At the trial of Dion Wayne Sanders, for example, after the trial court excluded testimony regarding the defendant's low serotonin in the CSF during the guilt phase of the trial, testimony regarding the "serotonin defense" was introduced during the penalty phase of the trial. The defense argued that Sanders inherited a predisposition for low serotonin brain activity, which left him vulnerable for impaired impulse control. Sanders also had a family history of violence associated with alcoholism. Also, Sanders had been using cocaine heavily prior to the murders. Although the jury found Sanders guilty of capital offenses, they returned verdicts of life without parole rather than the death penalty (22).

\section{State v. Newton}

In another Ohio case, the court denied a capital defendant's motion requesting funding for neuropsychiatric testing to "help explain [the defendant's] impulsiveness and alleged criminal behavior" (23). The defense requested the court to reconsider, pointing to "literature indicating a link between low levels of the brain chemical serotonin and deficient impulse control, leading to pyromania, suicide, and severe aggression," and arguing that such tests could provide mitigating evidence (p. 609) (23). The appellate court affirmed, noting two hurdles: (1) "Newton's claim that a low 
serotonin level is related to impulsivity simply did not matter since Newton failed to demonstrate that tests performed in December 2002 could be useful in determining Newton's brain chemistry in November 2001, when the offense occurred" (p. 609) (23), and (2) the funding denial was not prejudicial as the circumstances of the crime demonstrated planning and calculation by the defendant rather than impulsivity (p. 610) (23). More specific genotyping evidence would overcome the first hurdle, but a defendant would still need to demonstrate a causal link between his genotype and the criminal act in question.

\section{State v. Hill}

Finally, in South Carolina, David Hill was convicted of firstdegree murder and sentenced to death in 1995. During the sentencing phase of his capital trial, Hill's lawyers introduced expert testimony to establish that Hill suffered from a genetically based serotonin deficiency, which caused him to have aggressive impulses (24). His lawyers argued the death penalty was unwarranted "because Hill's aggressive behavior was genetic (i.e., beyond his control) and treatable" (p. 202) (24). In support of this defense, his lawyers introduced several experts to testify that Hill had chronically low serotonin levels (based on analysis of CSF), regarding the role of serotonin on brain chemistry, and how genetics can affect serotonin levels. The defense also introduced a psychiatrist to testify that he had prescribed Prozac to Hill that Hill had responded favorably, and the medication curbed his aggressive impulses. Unfortunately, the psychiatrist suffered a breakdown on the stand and was unable to answer questions. On appeal, Hill unsuccessfully argued that he received ineffective assistance of counsel during trial by calling the psychiatrist to the stand.

In short, specific evidence regarding the MAOA gene or serotonin abnormalities has been introduced in only a few criminal cases. Such evidence may support the use of a defense of diminished capacity, where permissible, to inform the trier of fact whether the defendant had the capacity to form the requisite intent for the alleged crime, or serve as mitigating evidence during sentencing. Because of procedural obstacles or limitations in the scientific research to date, such testimony has either been excluded or has had minimal effect on trial outcome. In at least two cases, however, such testimony may have influenced the jury's decision to convict the defendant of second-degree rather than first-degree murder. In both cases, however, the defendant was convicted of murder rather than manslaughter, suggesting those jurors did not believe the defendant's serotonin level rendered him incapable of forming the intent to kill. If introduced during the initial trial, and presented within the statutory limits of the respective jurisdiction, such evidence may play a more prominent role in future criminal cases.

\section{$M A O A$ and Environment Interaction}

In the future, testimony regarding behavioral genetics will likely go beyond the simplistic notions of the MAOA knockout gene and low levels of a serotonin metabolite in the CSF. It is likely that research regarding genetics and environmental interactions will be the basis for such testimony. Research by Caspi et al. $(3,4)$ and others will be presented in legal settings.

Caspi et al. (2002) (3) "studied a large sample of male children from birth to adulthood to determine why some children who are maltreated grow up to develop antisocial behavior, whereas others do not." The subjects, who were followed from age 3 to age 26, were members of the Dunedin Multidisciplinary Health and Development Study. The New Zealand researchers used a particular gene, the MAOA gene, to characterize genetic susceptibility to maltreatment. The MAOA gene is located on the $\mathrm{X}$ chromosome (Xp11.23-11.4). This gene encodes the MAOA enzyme, which metabolizes neurotransmitters such as serotonin, norepinephrine, and dopamine. There are two alleles of the MAOA gene: one results in high activity of the $M A O A$ enzyme; the other results in low activity of the MAOA enzyme. As this gene is on the $\mathrm{X}$ chromosome, a male has only one allele, either the high activity MAOA or the low activity $M A O A$ allele. A male with the low activity $M A O A$ allele will not metabolize serotonin, norepinephrine, and dopamine in an efficient manner. In the Caspi et al. study, about $37 \%$ of the males had low activity of the MAOA enzyme.

When they characterized the subjects regarding childhood maltreatment, Caspi et al. (2002) (3) found that $8 \%$ of the children suffered "severe" maltreatment between ages 3 and 11;28\% of the children suffered "probable" maltreatment; and $64 \%$ experienced no maltreatment. These researchers found that when male subjects had a low activity of the MAOA enzyme and also were maltreated as children, there was a much greater likelihood the person would manifest violent antisocial behavior in the future. They said, "For adult violent conviction, maltreated males with the low-MAOA activity genotype were more likely than nonmaltreated males with this genotype to be convicted of a violent crime by a significant odds ratio of 9.8." The authors thought that this study illustrated a model for gene-environment interaction. That is, they suggested that the high activity MAOA allele protects the child against the harmful biopsychosocial impact of maltreatment.

For purposes of testimony in criminal trials, it is useful to compare subjects who had low MAOA activity and severe maltreatment with subjects who had high $M A O A$ activity and no maltreatment. In presenting mitigation, the point is that the defendant's low $M A O A$ activity and severe child maltreatment were outside of his control. If a defendant had both of those characteristics, he had vulnerability toward violent behavior. In analyzing the data of Caspi et al. (2002) (3), we found that the relative risk for being convicted of a violent offense was 4.6 for individuals who had low MAOA activity and severe maltreatment compared with subjects who had high MAOA activity and no maltreatment. See Table 1, which indicates the relative risk for violent behavior, not the absolute risk.

\section{Replication of Caspi et al. (2002)}

The study by Caspi et al. (2002) (3) was replicated by several other research teams which used varying definitions of child maltreatment, violent behavior, and genetic risk. The fact that the results are mostly consistent even though there are a variety of study designs should strengthen the conclusion that a $G \times E$ interaction increases one's risk to be a violent person later in life. See Table 2 for a summary of studies that addressed the relationship of $M A O A$ genotype, maltreatment, and antisocial behavior. There were five studies (25-29) that replicated Caspi et al. (2002) (3). The two studies $(30,31)$ that did not replicate had significant limitations. Kim-Cohen et al. recently reviewed this research, developed a meta-analysis of these studies, and said, "Pooling estimates from

TABLE 1-Data adapted from Caspi et al. (2002).

\begin{tabular}{lcc}
\hline Condition & $\begin{array}{c}\text { Percent convicted of } \\
\text { violent offense }\end{array}$ & $\begin{array}{c}\text { Relative } \\
\text { risk }\end{array}$ \\
\hline High MAOA, no maltreatment & 7 & 1 \\
High MAOA, maltreatment & 20 & 2.9 \\
Low MAOA, maltreatment & 32 & 4.6 \\
\hline
\end{tabular}

MAOA, monoamine oxidase A. 


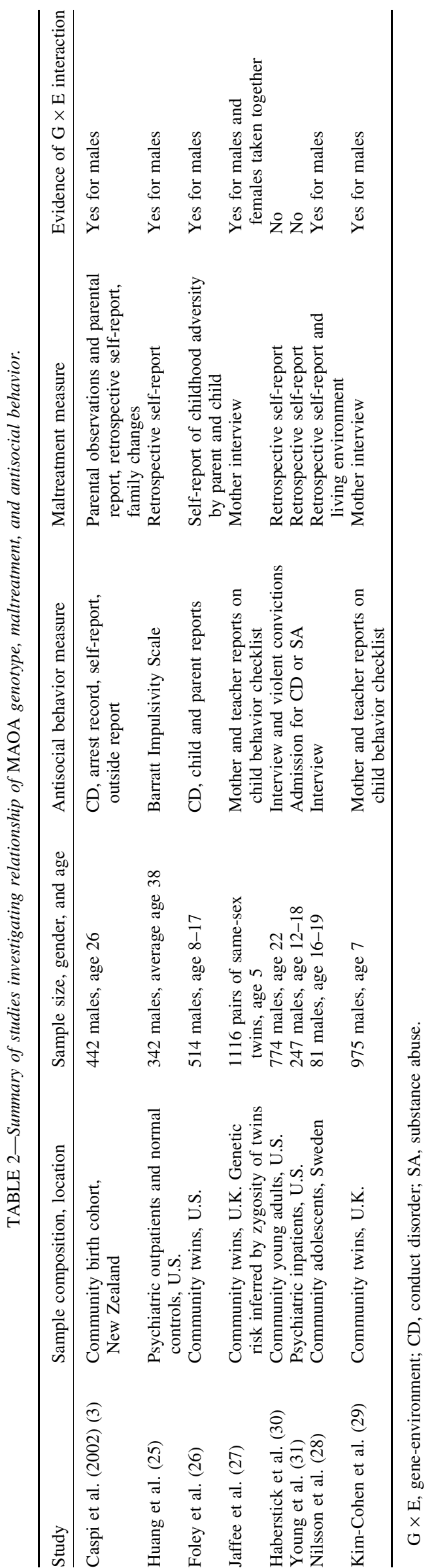

five studies, we found that the association between early familial adversity and mental health was significantly stronger in the lowactivity MAOA versus the high-activity MAOA groups" (29).

\section{SLC6A4 and Environment Interaction}

Caspi et al. (2003) (4) addressed "why stress experiences lead to depression in some people but not in others." The subjects in this study were also members of the Dunedin Multidisciplinary Health and Development Study. The authors found another example of $\mathrm{G} \times \mathrm{E}$ interaction, i.e., that a particular allele of the serotonin transporter gene appeared to protect individuals from the harmful biopsychosocial impact of multiple stressors.

The transporter is the cell membrane structure that recycles synaptic serotonin (5-hydroxytryptamine or 5-HT) for repackaging and subsequent re-release. The serotonin transporter gene is referred to as 5-HTT or SLC6A4. The SLC6A4 gene, which is located on chromosome 17, can have either a "long allele" or a "short allele." The short allele of the SLC6A4 gene causes low activity of the transporter system, which means there will be more serotonin in the synapse and less serotonin available for reuse. For people with the short allele, the serotonin system is not working efficiently. In Caspi et al. (2003) (4), 17\% of the subjects had two copies of the short allele (S/S homozygotes), 31\% had two copies of the long allele (L/L homozygotes), and $51 \%$ had one copy of each allele (S/L heterozygotes).

Caspi et al. (2003) (4) characterized the subjects as to whether they had stressful life events after their 21st birthday and prior to their 26th birthday. For example, they asked about stressful life events related to employment, finances, housing, health, and relationships. They found the following frequency of stressful life events: no stressful life events, $30 \%$ of the sample; one event, $25 \%$ of the sample; two events, $20 \%$ of the sample; three events, $11 \%$ of the sample; and four or more events, $15 \%$ of the sample. At about age 26, they characterized the subjects as to whether they had symptoms of serious depression. They found that $17 \%$ of study members met criteria for a past-year major depressive episode and $3 \%$ of study members reported past-year suicide attempt or recurrent suicidal ideation. The authors showed that individuals with the short allele of the 5-HTT were more susceptible to stress. Specifically, people with one or two copies of the short allele "exhibited more depressive symptoms, diagnosable depression, and suicidality in relation to stressful life events" than individuals with two long alleles.

For purposes of testimony in criminal trials, it is useful to compare subjects who were homozygotic for the short allele $(\mathrm{S} / \mathrm{S})$ and had four or more stressful life events with subjects who were homozygotic for the long allele $(\mathrm{L} / \mathrm{L})$ and had no stressful life events. In presenting mitigation, for instance, the point is that the defendant's low SLC6A4 activity and multiple stressful life experiences were outside of his control. If a defendant had both of those characteristics, he had vulnerability toward depression and suicidality. In some circumstances, severe depression may be a factor in mitigation. In analyzing the data of Caspi et al. (2003) (4), we found that the relative risk for suicidality was 4.7 for individuals who were $\mathrm{S} / \mathrm{S}$ homozygote and had four or more stressful life experiences compared with subjects who were $\mathrm{L} / \mathrm{L}$ homozygote and had no stressful life experiences. See Table 3. Also, we found that the relative risk for major depressive disorder was 4.0 for individuals who were $\mathrm{S} / \mathrm{S}$ homozygote and had four or more stressful life experiences compared with subjects who were L/L homozygote and had no stressful life experiences. See Table 4. 
TABLE 3-Data adapted from Caspi et al. (2003).

\begin{tabular}{lcc}
\hline Condition & $\begin{array}{c}\text { Percent } \\
\text { suicidal }\end{array}$ & $\begin{array}{c}\text { Relative } \\
\text { risk }\end{array}$ \\
\hline L/L Homozygote, no stressful life experience & 3 & 1 \\
L/L Homozygote, 4+ stressful life experiences & 4.5 & 1.5 \\
S/S Homozygote, 4+ stressful life experiences & 14 & 4.7 \\
\hline
\end{tabular}

TABLE 4-Data adapted from Caspi et al. (2003).

\begin{tabular}{|c|c|c|}
\hline Condition & $\begin{array}{l}\text { Percent with major } \\
\text { depressive disorder }\end{array}$ & $\begin{array}{l}\text { Relative } \\
\text { risk }\end{array}$ \\
\hline L/L Homozygote, no stressful life experience & 10 & 1 \\
\hline L/L Homozygote, 4+ stressful life experiences & 20 & 2.0 \\
\hline S/S Homozygote, 4+ stressful life experiences & 42 & 4.2 \\
\hline
\end{tabular}

\section{Replication of Caspi et al. (2003)}

The general findings of Caspi et al. (2003) (4) were replicated by several other research teams, which used varying definitions of psychosocial stressors, psychological distress, and genetic risk. They used a variety of study designs. See Table 5 for a summary of studies that addressed the relationship of SLC6A4 genotype, stressful life experiences, depression, and suicidality. Seven of these studies replicated (32-36) or partly replicated $(37,38)$ Caspi et al. (2003). Two studies $(39,40)$ did not replicate Caspi et al. (2003). Also, research regarding the SLC6A4 polymorphism, stressful life events, and depression was summarized and reviewed by Wurtman (41) and Zammit and Owen (42).

\section{Methods}

Between August 2004 and October 2006, faculty of Vanderbilt Forensic Services have arranged for MAOA and SLC6A4 genotyping of 15 defendants. All of these defendants were being prosecuted by the State of Tennessee for first-degree murder or attempted first-degree murder, as well as other serious offenses in some cases. In several cases, the state was seeking the death penalty. We conducted genotyping because we thought it might be relevant for the guilt phase of the trial (regarding diminished capacity) and/or the penalty phase of the trial (regarding mitigation). In four cases, the defendants were minors, so the death penalty was not an issue. However, evidence regarding genotyping may be relevant in transfer or waiver hearings, in which the court decides whether a minor will be tried in juvenile court or criminal court.

This research was reviewed by the Institutional Review Board (IRB) of Vanderbilt University School of Medicine, and it was concluded this activity met criteria for Exempt Review. The IRB noted, "The study poses minimal risk to participants." The clinical information presented below is either publicly available because it was introduced at trial or is disguised to make it nonidentifiable.

\section{Sample Preparation and PCR Amplification of the MAOA and SLC6A4 Genes}

The genotyping was performed by faculty of the Molecular Genetics Laboratory, Vanderbilt University Medical Center (CVJ). High molecular weight DNA was extracted from $350 \mu \mathrm{L}$ of peripheral blood collected in EDTA tubes using the BioRobot EZ1 and EZ1 DNA extraction kits according to the instructions from the manufacturer (Qiagen Inc., Valencia, CA). Approximately 50-100 ng of patient DNA was used in each polymerase chain

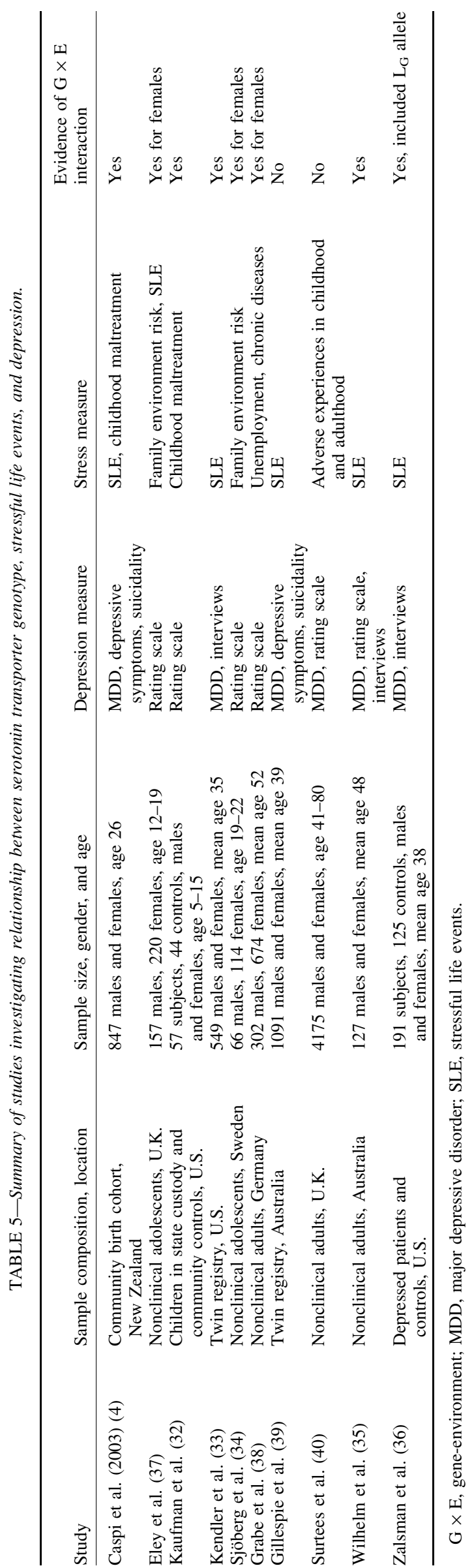


reaction (PCR) assay. Amplification of the $M A O A$ variable number tandem repeat polymorphism was performed using oligonucleotide primers specific for this locus as previously described by Caspi et al. (2002) (3). However the forward primer was labeled with the HEX fluorophore. The $15 \mu \mathrm{L}$ PCR reaction contained $0.1 \mu \mathrm{M}$ of each primer and included an initial denaturation at $94^{\circ} \mathrm{C}$ for $6 \mathrm{~min}$ followed by 35 cycles each containing denaturation at $94^{\circ} \mathrm{C}$ for $1 \mathrm{~min}$, annealing at $62^{\circ} \mathrm{C}$ for $1 \mathrm{~min}$, and a $1.5 \mathrm{~min}$ extension at $72^{\circ} \mathrm{C}$. The amplification reaction concluded with a 10 min extension at $72^{\circ} \mathrm{C}$. Amplification of the SLC6A4 gene promoter polymorphism was performed using oligonucleotide primers specific for this locus as first reported by Gelernter et al. (40). However, the forward primer was labeled with the NED fluorophore. The $15 \mu \mathrm{L}$ PCR reaction contained $0.5 \mu \mathrm{M}$ of each primer and included an initial denaturation at $94^{\circ} \mathrm{C}$ for 6 min followed by 35 cycles each containing denaturation at $94^{\circ} \mathrm{C}$ for $30 \mathrm{sec}$, annealing at $66^{\circ} \mathrm{C}$ for $30 \mathrm{sec}$, and a $45 \mathrm{sec}$ extension at $72^{\circ} \mathrm{C}$. The amplification reaction concluded with a $10 \mathrm{~min}$ extension at $72^{\circ} \mathrm{C}$.

\section{Capillary Electrophoresis and Analysis}

One microliter of the PCR products were prepared for analysis on the 3130xl Genetic Analyzer (Applied Biosystems, Foster City, CA) by mixing with $19.5 \mu \mathrm{L}$ of $\mathrm{Hi}$-Di formamide and $0.5 \mu \mathrm{L}$ of ROX-labeled DNA size standards, both obtained from Applied Biosystems. Electrokinetic injection of the DNA into the capillaries occurred at $2400 \mathrm{~V}$ for $23 \mathrm{sec}$. Amplicons were separated using the POP-7 polymer and were analyzed using GeneMapper v3.7 (Applied Biosystems). Using this system, MAOA alleles are $\sim 287$ base pairs (bp), $317 \mathrm{bp}, 335 \mathrm{bp}, 347 \mathrm{bp}$, and $377 \mathrm{bp}$ corresponding to alleles 2, 3, 3.5, 4, and 5, respectively (Fig. 1, Panel a). As this gene is on the $\mathrm{X}$ chromosome, males will have one allele generating a single peak at any of one of these sizes while females may be homozygous for one allele to generate a single peak or heterozygous for two different alleles generating two distinct peaks. Using this methodology, the SLC6A4 short allele yields amplicons $\sim 370$ bp in length while the long allele generates amplicons 412 bp in length (Fig. 1, Panel b). As this gene is on an autosome, 17q11.2, an individual can be homozygous for either the short or long allele generating a single peak at the corresponding size or heterozygous with both a short and long allele with amplicons at 370 and 412 bp, respectively.

\section{Results}

The authors conducted MAOA and SLC6A4 genotyping on 15 defendants. See Table 6 for information regarding the defendants' gender, age, charges, and results of MAOA and SLC6A4 genotyping. Most of the defendants had unremarkable results on genotyping. Several defendants (for example, "AA," "CC," "DD," "EE," and "FF") had results that may be appropriate to present regarding diminished capacity, mitigation, or waiver to criminal court. By the time, this manuscript was submitted for publication, the authors had limited experience in testifying regarding genotyping of defendants. Six case vignettes are summarized here.

\section{Testimony Regarding "AA"}

AA was a 14-year-old Caucasian male who faced an unusual number and intensity of psychosocial stressors. He became seriously depressed and suicidal, and one morning he woke up and considered committing suicide that day. He obtained a handgun from his father's gun cabinet and loaded it. When it was time to
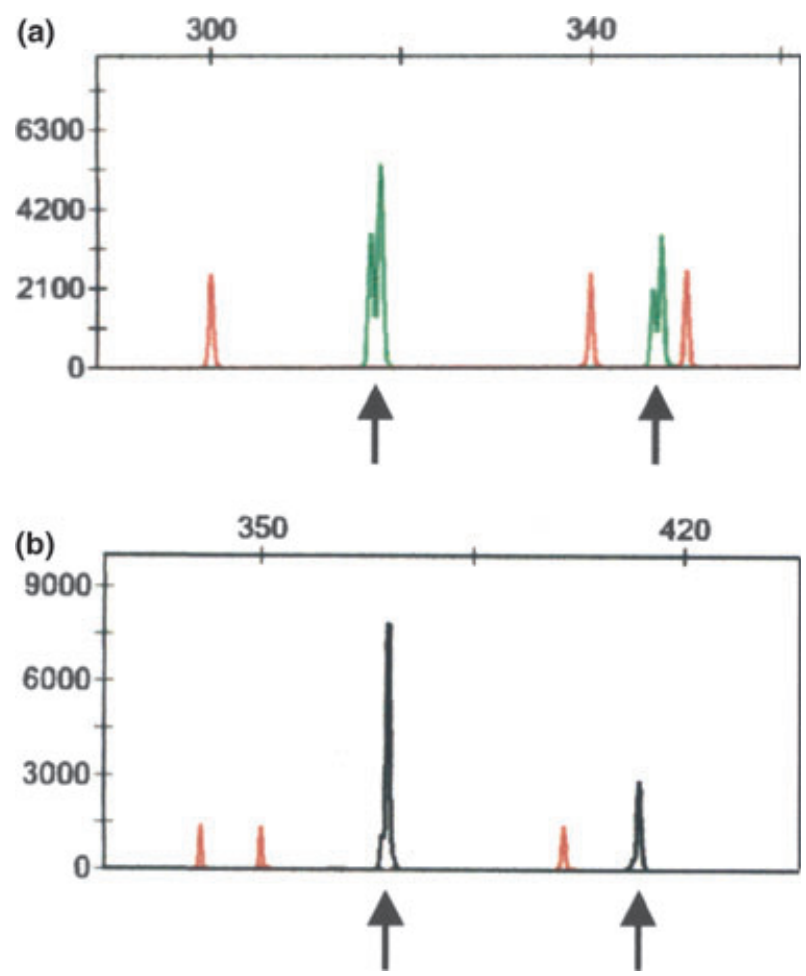

FIG. 1-Electropherograms obtained from the 3130 xl Genetic Analyzer following amplification of genomic DNA by PCR for the MAOA (panel a) and SLC6A4 (panel b) genes. DNA size standards labeled with the ROX fluorophore are displayed as red and correspond to DNA fragments at 300, 340 , and 350 in panel (a) and 340, 350, and 400 in panel (b). The intensity of fluorescence measured by the instrument thus generating the peak height for each allele is noted on the y-axis. MAOA alleles of 3 and 4 from a female patient are displayed in green and denoted by arrows. SLC6A4 short (S) and long $(L)$ alleles from a patient heterozygous for this polymorphism are displayed in black and denoted by arrows.

TABLE 6-Defendants who were genotyped.

\begin{tabular}{|c|c|c|c|c|}
\hline Defendant & Gender/Age & MAOA & SLC6A4 & Relevant charges \\
\hline 01 & $3 / 20$ & 4 & $\mathrm{~S} / \mathrm{L}$ & First-degree murder \\
\hline 02 & $\hat{\sigma} / 28$ & 4 & $\mathrm{~S} / \mathrm{L}$ & First-degree murder \\
\hline 03 & $+9 / 24$ & $3 / 4$ & $\mathrm{~L} / \mathrm{L}$ & $\begin{array}{l}\text { Attempted first-degree } \\
\text { murder }\end{array}$ \\
\hline 04 & $3 / 44$ & 4 & $\mathrm{~L} / \mathrm{L}$ & $\begin{array}{l}\text { First-degree murder, } \\
\text { aggravated rape }\end{array}$ \\
\hline 05 (“AA”) & $3 / 14$ & 4 & $\mathrm{~S} / \mathrm{S}$ & First-degree murder \\
\hline 06 & $\hat{3} / 40$ & 4 & $\mathrm{~S} / \mathrm{L}$ & First-degree murder \\
\hline 07 (“'BB”) & $3 / 42$ & 4 & $\mathrm{~L} / \mathrm{L}$ & $\begin{array}{l}\text { First-degree murder } \\
(2 \text { counts), } \\
\text { Attempted first-degree } \\
\text { murder }\end{array}$ \\
\hline 08 (“'CC”) & $s / 17$ & 4 & $\mathrm{~S} / \mathrm{S}$ & $\begin{array}{l}\text { First-degree murder } \\
(2 \text { counts })\end{array}$ \\
\hline 09 & $5 / 27$ & 4 & $\mathrm{~L} / \mathrm{L}$ & First-degree murder \\
\hline 10 (“DD”) & $3 / 45$ & 4 & $\mathrm{~S} / \mathrm{L}$ & First-degree murder \\
\hline 11 (“EE”) & $3 / 29$ & 3 & $\mathrm{~S} / \mathrm{S}$ & $\begin{array}{l}\text { First-degree murder } \\
(2 \text { counts })\end{array}$ \\
\hline 12 ("FF") & $3 / 45$ & 3.5 & $\mathrm{~S} / \mathrm{S}$ & First-degree murder ( 2 counts) \\
\hline 13 & $3 / 16$ & 3 & $\mathrm{~L} / \mathrm{L}$ & Reckless homicide \\
\hline 14 & $\pi / 26$ & 4 & $\mathrm{~L} / \mathrm{L}$ & First-degree murder \\
\hline 15 & $3 / 15$ & 4 & $\mathrm{~L} / \mathrm{L}$ & $\begin{array}{l}\text { First-degree murder, attempted } \\
\text { first-degree murder }\end{array}$ \\
\hline
\end{tabular}

"Age" refers to the defendant's age at the time of the alleged offense. In MAOA genotyping, the " 3 " and " 3.5 " alleles are associated with low $M A O A$ enzyme activity; the " 4 " allele is associated with high MAOA enzyme activity. In SLC6A4 genotyping, the "S" or short allele is associated with low serotonin transporter activity; the "L" or long allele is associated with high serotonin transporter activity. 
go to school, AA approached the school bus and fatally shot the bus driver.

On genetic testing, AA had the high activity $M A O A$ allele (4 repeats) and was homozygous, S/S, for the SLC6A4 gene. AA, a juvenile, was transferred to criminal court. At the trial, one of us (WB) testified for the defense and explained the significance of the SLC6A4 genotyping, i.e., that AA had a genetic vulnerability to become depressed under severe stress and that he was, in fact, depressed. The prosecution did not object to the presentation of this evidence. However, the testimony did not appear to have any effect on the outcome of the trial; the jury found the defendant guilty of first-degree murder.

\section{Testimony Regarding " $B B$ "}

BB was a 42-year-old Caucasian man who was accused of murdering his wife and daughter and attempting to murder his son. On genetic testing, $\mathrm{BB}$ had the high activity MAOA allele (4 repeats) and was homozygous, $\mathrm{L} / \mathrm{L}$, for the $S L C 6 A 4$ gene. At BBs trial, one of us (SAM) testified for the defense during the guilt phase of the trial. Although the genotyping turned out not to be relevant to the issues at the trial, the expert testified that genetic testing was conducted as part of a comprehensive forensic evaluation. The expert testified that no genetic factors were identified that might predispose BB to violence. This was significant in that neither the prosecution nor the court objected to the presentation of this evidence.

\section{Testimony Regarding "CC"}

CC was a 17-year-old Hispanic male day-laborer, who was involved in the death of a pregnant woman. Reportedly, CC was a passenger in a truck driven by a friend, who thought he struck and injured the woman. When they returned to investigate, one or both of the men shot and killed the woman and the unborn child. It was not clear who shot the woman.

On genetic testing, $\mathrm{CC}$ had the high activity MAOA allele (4 repeats) and was homozygous, $\mathrm{S} / \mathrm{S}$, for the SLC6A4 gene. At $\mathrm{CCs}$ trial, one of us (WB) planned to testify for the defense and explain how CCs genetic makeup might have a bearing on the issues of diminished capacity and mitigation. However, the prosecuting attorney objected to the nature of this testimony. Although the judge ruled that the testimony was admissible, the prosecuting attorney filed an interlocutory appeal to the Court of Criminal Appeals in order to block the testimony of the defense expert. The Tennessee Court of Criminal Appeals did not object to the expert's testimony regarding genotyping, but criticized the proposed testimony because the expert did not testify that the defendant completely lacked the mental capacity to commit the crimes (43).

\section{Testimony Regarding “DD”}

DD was a 45-year-old Caucasian male who killed an elderly female storekeeper. He was found guilty of first-degree murder in 2002 and given the death penalty. As part of DDs direct appeal, his attorney requested genetic testing for the MAOA and SLC6A4 genes. On genetic testing, DD had the high activity $M A O A$ allele (4 repeats) and was heterozygous, $\mathrm{S} / \mathrm{L}$, for the SLC6A4 gene. This case is instructive because the court commented on the usefulness of genetic testing in the order authorizing the MAOA and SLC6A4 genotyping. Regarding DD, the order said, "The Court recognizes...the possibility that this information...might have influenced the jury's decision in the penalty phase of the trial as to whether to select death as the proper punishment for [DD]. ...The Court finds, as a matter of law, that the expert services sought are necessary to ensure that the constitutional rights of the Defendant are properly protected." The statement in the court order suggests that not only is genetic testing acceptable to present in a trial with a possible outcome of the death penalty, but it might even be considered an expected component of the individual's defense.

\section{Testimony Regarding “EE”}

EE was an approximately 25-year-old male who was charged with two counts of first-degree murder, and his attorney requested $M A O A$ and SLC6A4 genotyping. On genetic testing, EE had the low activity $M A O A$ allele (3 repeats) and was homozygous, $\mathrm{S} / \mathrm{S}$, for the SLC6A4 gene. EE had environmental factors that may have interacted with the low activity $M A O A$ allele (a history of severe physical discipline) and the short alleles of the SLC6A4 gene (significant multiple stressors at the time of the alleged offenses). This was our only case in which the defendant had both of the $G \times E$ vulnerabilities discussed in this paper. EE's defense team may want to introduce the results of the genetic testing at his trial.

\section{Testimony Regarding " $F F$ "}

FF was a 43-year-old Caucasian male who found his estranged wife and her boyfriend in bed together and shot and killed both of them. FF was charged with two counts of first-degree murder. One of us (WB) conducted a comprehensive pretrial forensic psychiatric evaluation on behalf of the defense, which included genotyping. On genetic testing, FF had the high activity $M A O A$ allele (4 repeats) and was homozygous, $\mathrm{S} / \mathrm{S}$, for the SLC6A4 gene. FF had environmental factors that may have interacted with the short allele of the SLC6A4 gene (multiple significant psychosocial stressors).

At the trial, the forensic expert proposed to testify regarding the issues of diminished capacity and mitigation. After a brief Daubert hearing, however, the court ruled that behavioral genomics was not yet scientific enough to present as testimony before a jury. The expert was allowed to testify about other aspects of the evaluation, but not regarding the genotyping.

\section{Discussion and Conclusion}

The authors of this paper are neither advocating nor criticizing the presentation of evidence regarding a defendant's genotype at a criminal trial. We are simply presenting the current state of research regarding this topic and our limited experience regarding testimony. The research regarding $\mathrm{G} \times \mathrm{E}$ interaction summarized in this paper is in an early stage of development, as is our testifying about this research in criminal trials.

It seems possible that both the defense and the prosecution may be interested in introducing evidence regarding a defendant's life experiences and genetic makeup to a jury. In a case of aggravated assault, for instance, the prosecution may say that a defendant has violent tendencies (based on the person's genotype conveying low MAOA activity and a history of severe child maltreatment), and should be removed from society for as long as possible. On the other hand, the defense may say during the sentencing phase of a first-degree murder case that a person's genotype and history of severe abuse during childhood is mitigating. 
That is, the defense attorney might argue that the person will at least receive a life sentence and poses no future danger to society, but the person should not receive the death penalty because his behavior was at least partly caused by his genetic makeup and his adverse life experiences.

The underlying science for the testimony discussed in this paper is derived from several disciplines: in child development and psychology, the ability to identify abused and nonabused children in a systematic manner and follow them prospectively for more than 20 years; in psychology and psychiatry, the ability to collect reliable information regarding a person's life experiences, psychological symptoms, and mental disorders; and in molecular genetics, the ability to map the human genome and identify genes that encode specific enzymes. The identification and study of $\mathrm{G} \times \mathrm{E}$ interactions is an area of active research in the field of psychiatric molecular genetics. Early research in this area has created a roadmap for scientists interested in "investigating interactions between measured genes and measured environments" (44).

The future of behavioral genetics and the role of this new science in criminal trials seems wide-open. This article addressed the possible usefulness of genotyping for only two genes as a component of a pretrial forensic psychiatric evaluation when diminished capacity, mitigation, and waiver to criminal court are issues. One can easily imagine how other important legal issues might be addressed through behavioral genetics. For example, perhaps specific groups of genes will be identified that make a person vulnerable to serious mental illnesses such as schizophrenia and bipolar disorder. Criminal defendants may seek testing for these gene variants to support a claim of legal insanity. Also, perhaps specific groups of genesalong with life experiences-will be identified that make a person vulnerable to become a dangerous, intractable sex offender. Such information may have a bearing on the decision to release such individuals from institutions (either penal or psychiatric) into the community. A rational approach to this "next frontier for the world of criminal justice" (1) will require a foundation of solid science, capable psychiatry, and good law.

\section{Acknowledgments}

The authors thank colleagues who encouraged this research and made helpful suggestions: Stephan Heckers, M.D.; Ronald Salomon, M.D.; James S. Walker, Ph.D.; William Newman, M.D.; and Ms. Patricia Lee, Eskind Biomedical Library.

\section{References}

1. Appelbaum PS. Behavioral genetics and the punishment of crime. Psychiatr Serv 2005;56:25-7.

2. Popma A, Raine A. Will future forensic assessment be neurobiologic? Child Adolesc Psychiatr Clin N Am 2006;15:429-44.

3. Caspi A, McClay J, Moffitt TE, Mill J, Martin J, Craig IW, et al. Role of genotype in the cycle of violence in maltreated children. Science 2002;297:851-4.

4. Caspi A, Sugden K, Moffitt TE, Taylor A, Craig IW, Harrington H, et al. Influence of life stress on depression: moderation by a polymorphism in the 5-HTT gene. Science 2003;301:386-9.

5. Lombroso C. L'uomo delinquente. Torino, Italy: Fratelli Bocca, 1876

6. Wolfgang ME. Pioneers in criminology: Cesare Lombroso (1835-1909). J Crim Law Criminol Police Sci 1961;52:361-91.

7. Sheldon WH, Hartl EM, McDermott E. Varieties of delinquent youth: an introduction to constitutional psychiatry. New York: Harper, 1949.

8. Kendler KS, Prescott CA. Genes, environment, and psychopathology. New York, NY: Guilford, 2006.

9. Witkin HA, Mednick SA, Schulsinger F, Bakkestrom E, Christiansen $\mathrm{KO}$, Goodenough DR, et al. Criminality in XYY and XXY men. Science 1976;193:547-55.
10. Gotz MJ, Johnstone EC, Ratcliffe SG. Criminality and antisocial behaviour in unselected men with sex chromosome abnormalities. Psychol Med 1999;29:953-62.

11. Farahany N, Coleman J. Genetics and responsiblity: to know the criminal from the crime. Law Contemp Probl 2006;69:115.

12. Farahany N, Bernet W. Behavioural genetics in criminal cases: past, present, and future. Genomics Soc Policy 2006;2:72-9.

13. Mobley v. State, 455 S.E.2d 61 (Ga. Sup. Ct. 1995).

14. Reply Brief for Appellant 1994, 1994 WL 16047246 (Ga. 1994).

15. Brunner HG, Nelen M, Breakefield XO, Ropers HH, Van Oost BA. Abnormal behavior associated with a point mutation in the structural gene for monoamine oxidase A. Science 1993;262:578-80.

16. Hall v. State, 2005 WL 22951 (Tenn. Crim. App. 2005).

17. Hines v. State, 2004 WL 1567120 (Tenn. Crim. App. 2004).

18. State v. Payne, 2002 WL 31624813 (Tenn. Crim. App. 2002).

19. State v. Godsey, 2001 WL 1543474 (Tenn. Crim. App. 2001).

20. People v. Uncapher, 2004 WL 790329 (Mich. App. 2004).

21. State v. Sanders, 2000 WL 1006574 (Ohio App. 2 Dist. 2000).

22. Rossby P. The biology of violence: serotonin, alcoholism, hypoglycemia. Crim Justice 2007;17:20-4.

23. State v. Newton, 840 N.E.2d 593 (Ohio 2006).

24. Hill v. Ozmint, 339 F.3d 187 (4th Cir. 2003).

25. Huang YY, Cate SP, Battistuzzi C, Oquendo MA, Brent D, Mann JJ. An association between a functional polymorphism in the monoamine oxidase a gene promoter, impulsive traits and early abuse experiences. Neuropsychopharmacology 2004;29:1498-505.

26. Foley DL, Eaves LJ, Wormley B, Silberg JL, Maes HH, Kuhn J, et al. Childhood adversity, monoamine oxidase a genotype, and risk for conduct disorder. Arch Gen Psychiatry 2004;61:738-44.

27. Jaffee SR, Caspi A, Moffitt TE, Dodge KA, Rutter M, Taylor A, et al. Nature X nurture: genetic vulnerabilities interact with physical maltreatment to promote conduct problems. Dev Psychopathol 2005;17:67-84.

28. Nilsson KW, Sjoberg RL, Damberg M, Leppert J, Ohrvik J, Alm PO, et al. Role of monoamine oxidase A genotype and psychosocial factors in male adolescent criminal activity. Biol Psychiatry 2006;59:121-7.

29. Kim-Cohen J, Caspi A, Taylor A, Williams B, Newcombe R, Craig IW, et al. MAOA, maltreatment, and gene-environment interaction predicting children's mental health: new evidence and a meta-analysis. Mol Psychiatry 2006;11:903-13.

30. Haberstick BC, Lessem JM, Hopfer CJ, Smolen A, Ehringer MA, Timberlake D, et al. Monoamine oxidase A (MAOA) and antisocial behaviors in the presence of childhood and adolescent maltreatment. Am $\mathbf{J}$ Med Genet B Neuropsychiatr Genet 2005;135:59-64.

31. Young SE, Smolen A, Hewitt JK, Haberstick BC, Stallings MC, Corley $\mathrm{RP}$, et al. Interaction between MAO-A genotype and maltreatment in the risk for conduct disorder: failure to confirm in adolescent patients. Am J Psychiatry 2006;163:1019-25.

32. Kaufman J, Yang BZ, Douglas-Palumberi H, Houshyar S, Lipschitz D, Krystal JH, et al. Social supports and serotonin transporter gene moderate depression in maltreated children. Proc Natl Acad Sci USA 2004;101:17316-21.

33. Kendler KS, Kuhn JW, Vittum J, Prescott CA, Riley B. The interaction of stressful life events and a serotonin transporter polymorphism in the prediction of episodes of major depression: a replication. Arch Gen Psychiatry 2005;62:529-35.

34. Sjöberg RL, Nilsson KW, Nordquist N, Ohrvik J, Leppert J, Lindstrom $\mathrm{L}$, et al. Development of depression: sex and the interaction between environment and a promoter polymorphism of the serotonin transporter gene. Int J Neuropsychopharmacol 2006;9:443-9.

35. Wilhelm K, Mitchell PB, Niven H, Finch A, Wedgwood L, Scimone A, et al. Life events, first depression onset and the serotonin transporter gene. Br J Psychiatry 2006;188:210-5.

36. Zalsman G, Huang YY, Oquendo MA, Burke AK, Hu XZ, Brent DA, et al. Association of a triallelic serotonin transporter gene promoter region (5-HTTLPR) polymorphism with stressful life events and severity of depression. Am J Psychiatry 2006;163:1588-93.

37. Eley TC, Sugden K, Corsico A, Gregory AM, Sham P, McGuffin P, et al. Gene-environment interaction analysis of serotonin system markers with adolescent depression. Mol Psychiatry 2004;9:908-15.

38. Grabe HJ, Lange M, Wolff B, Volzke H, Lucht M, Freyberger HJ, et al. Mental and physical distress is modulated by a polymorphism in the 5-HT transporter gene interacting with social stressors and chronic disease burden. Mol Psychiatry 2005;10:220-4.

39. Gillespie NA, Whitfield JB, Williams B, Heath AC, Martin NG. The relationship between stressful life events, the serotonin transporter 
(5-HTTLPR) genotype and major depression. Psychol Med 2005;35: $101-11$.

40. Surtees PG, Wainwright NW, Willis-Owen SA, Luben R, Day NE, Flint J. Social adversity, the serotonin transporter (5-HTTLPR) polymorphism and major depressive disorder. Biol Psychiatry 2006;59:224-9.

41. Wurtman RJ. Genes, stress, and depression. Metabolism 2005;54:16-9.

42. Zammit S, Owen MJ. Stressful life events, 5-HTT genotype and risk of depression. Br J Psychiatry 2006;188:199-201.

43. State v. Idellfonso-Diaz, 2006 WL 3093207 (Tenn. Crim. App. 2006).
44. Moffitt TE, Caspi A, Rutter M. Strategy for investigating interactions between measured genes and measured environments. Arch Gen Psychiatry $2005 ; 62: 473-81$.

Additional information and reprint requests:

William Bernet, M.D.

Vanderbilt Psychiatric Hospital

1601 Twenty-third Avenue South, Suite 3050

Nashville, TN 37212-3133

E-mail: william.bernet@vanderbilt.edu 